\title{
Camelina meal and chromium picolinate effects on broiler thigh meat nutritional properties
}

\author{
Arabela Elena Untea ${ }^{* 1}$, Tatiana Dumitra Panaite ${ }^{1}$, \\ Alexandra Oancea1, Raluca Paula Turcu ${ }^{1}$, Mihaela Saracila1 \\ *corresponding author: arabela.untea@ibna.ro
}

National Research and Development Institute for Biology and Animal Nutrition, 077015 Ilfov, Romania

\section{ABSTRACT}

The aim of this study was to evaluate the combined effects of trivalent chromium and camelina meal on proximate composition, mineral content and fatty acids profile of broiler chicken thigh meat. An experiment with 2 × 3 factorial arrangement was performed on 240 Ross 308 broiler chicken aged 14 days. Six dietary treatments were elaborated as follows: 0 and 3\% inclusion rate of Camelina meal and 0,200 and $400 \mu \mathrm{g} / \mathrm{kg}$ chromium picolinate (CrPic).

Supplementation of broiler diets with 3\% Camelina meal led to significantly $(\mathrm{P}<0.05)$ increased crude fat concentrations in thigh samples compared to control group or with single chromium supplemented groups. In thigh samples, $\mathrm{Zn}$ and Fe concentrations increased under CrPic influence and fatty acids profile was influenced by Camelina meal presence in the diets. In Camelina meal supplemented groups, were registered significantly increased omega 3 fatty acids concentrations compared to control group or single chromium supplemented groups.

The results of the present study found that Camelina meal and chromium picolinate supplements in broilers diets improved the nutritional properties of thigh meat, especially essential minerals content and fatty acids profile.

Keywords: chromium, camelina, broiler, minerals, fatty acids

\section{INTRODUCTION}

The incidence of coronary heart disease can be prevented by nutritional strategies with the aim of reducing saturated fatty acids (SFA) and cholesterol level from diets. Chicken meat is considered an economically viable source of 
polyunsaturated fatty acids (PUFA) and the lipid profile of meat can be nutritional manipulated (Mir et al., 2017).

Different nutritional strategies that imply terrestrial sources of PUFA, were applied in order to obtain PUFA enriched animal origin food. PUFA meat enrichment through animal nutrition strategy was mostly based on diets supplemented with linseed or flaxseed (Panaite et al., 2019; Kumar et al., 2020); camelina (Orczewska-Dudek \& Pietras, 2019; Untea et al., 2019); safflower (Amer et al., 2021); rapeseed (Gao et al., 2020) etc. Camelina meal was used in animal nutrition as feedstuff being considered a valuable source of protein and lipids, of which linolenic acid (ALA) represents 25-30\% (Panaite et al., 2016).

Nowadays, the essentiality of trivalent chromium is scientific recognized being required for a normal carbohydrate and lipid metabolism. The commercial diets for poultry cannot reach the chromium requirements and the growth performance can be affected by chromium defiency (Mir et al., 2017). Studies on the effects of chromium supplementation on poultry diets proved beneficial effects on growh performance (Toghyani et al., 2012), reducing the cholesterol level (Anandhi et al., 2006) and improving the meat oxidative stability (Untea et al., 2019; Sahin et al., 2003).

The aim of this study was to evaluate the combined effects of trivalent chromium and camelina meal on proximate composition, mineral content and fatty acids profile of broiler chicken thigh meat.

\section{MATERIALS AND METHODS}

The experiment complied with Directive 2010/63/EU on the protection of animals used for scientific purposes and the experimental procedures were approved by Ethical Commission of National Research and Development Institute for Biology and Animal Nutrition.

\section{Experimental design}

An experiment with $2 \times 3$ factorial arrangement was performed on 240 Ross 308 broiler chicken aged 14 days. Six dietary treatments were elaborated as follows: 0 and 3\% inclusion rate of Camelina meal and 0, 200 and 400 $\mu \mathrm{g} / \mathrm{kg}$ chromium picolinate (CrPic) (Sigma Aldrich, Germany). The ratio structures are presented in table 1.

A poultry experimental hall, digestibility pens and control monitoring system were as infrastructure in order to conduct the broiler experiment; $23 \mathrm{~h}$ light/1h darkness light regimen and each treatment was replicated 4 times. Free access to the water and ad libitum feeding was applied during experimental period. At the end of the experiment 6 chicks from each group 
were slaughtered and samples of thigh meat were collected for further analysis.

Table 1. Structure of recipes used in experiment

\begin{tabular}{|c|c|c|c|c|}
\hline \multirow[t]{2}{*}{ Diet composition (\%) } & \multicolumn{2}{|c|}{ Stage II grower (14-28 days) } & \multicolumn{2}{|c|}{ Stage III finisher (29-42 days) } \\
\hline & Cam 0\% & Cam 3\% & Cam $0 \%$ & Cam 3\% \\
\hline Maize & 34.17 & 34.98 & 39.77 & 39.75 \\
\hline Wheat & 15.00 & 15.00 & 15.00 & 15.00 \\
\hline Rice bran & 8.00 & 8.00 & 7.12 & 8.00 \\
\hline Soybean meal & 22.00 & 21.83 & 16.05 & 15.82 \\
\hline Rapeseed meal & 8.00 & 5.00 & 9.00 & 6.00 \\
\hline Gluten & 4.00 & 4.00 & 4.00 & 4.00 \\
\hline Soybean oil & 4.20 & 3.50 & 4.90 & 4.20 \\
\hline DL- Methionine & 0.15 & 0.15 & 0.13 & 0.14 \\
\hline Lysine & 0.27 & 0.29 & 0.30 & 0.32 \\
\hline Calcium carbonate & 1.25 & 1.27 & 1.11 & 1.14 \\
\hline Calcium phosphate & 1.54 & 1.56 & 1.37 & 1.39 \\
\hline Sodium chloride & 0.37 & 0.37 & 0.20 & 0.20 \\
\hline Choline & 0.05 & 0.05 & 0.05 & 0.05 \\
\hline Camelina meal & - & 3.00 & - & 3.00 \\
\hline Premix * & 1.00 & 1.00 & 1.00 & 1.00 \\
\hline Total & 100 & 100 & 100 & 100 \\
\hline \multicolumn{5}{|l|}{ Chemical composition } \\
\hline Dry matter & 88.02 & 88.26 & 87.96 & 88.23 \\
\hline M.E. poultry, (kcal/kg) & 3097.76 & 3101.75 & 3200.00 & 3200.00 \\
\hline Crude protein & 21.53 & 21.50 & 19.50 & 19.50 \\
\hline Crude fat & 6.15 & 5.78 & 6.86 & 6.51 \\
\hline Calcium & 0.87 & 0.87 & 0.78 & 0.78 \\
\hline Available phosphorous & 0.44 & 0.43 & 0.39 & 0.39 \\
\hline Lysine & 1.20 & 1.20 & 1.08 & 1.08 \\
\hline Methionine & 0.52 & 0.52 & 0.48 & 0.49 \\
\hline Met+cis & 0.92 & 0.91 & 0.85 & 0.85 \\
\hline Threonine & 0.73 & 0.72 & 0.65 & 0.64 \\
\hline Triphtopan & 0.21 & 0.21 & 0.18 & 0.18 \\
\hline
\end{tabular}

*One level of Camelina meal inclusion was split in 3 levels of Chromium inclusion: 0,20 and $40 \mathrm{mg} / \mathrm{kg}$ premix.

The chemical structure of premix was published before by Untea et al., 2019.

\section{Chemical analysis}

Proximate composition of thigh meat was determined as follows: crude protein by Kjeldahl method according SR EN ISO 5983-2, 2009 (Kjeltek auto 1030 - Tecator); crude fat by continuous solvent extraction (SR ISO 6492, 2001) and crude ash by gravimetric method.

Trace minerals determinations $(\mathrm{Cu}, \mathrm{Fe}, \mathrm{Mn}, \mathrm{Zn})$ was performed using a Thermo Electron - SOLAAR M6 Dual Zeeman Comfort (Cambridge, UK) equipment and the method published by Untea et al., (2012).

Fatty acids determinations: A system consists of Perkin-Elmer Clarus 500 (Massachusetts, United States) gas chromatograph, Flame Ionization Detector (FID), capillary separation column with high polar stationary phase TRACE TR-Fame, (Thermo Electron, Massachusetts, United States), dimensions $60 \mathrm{~m} \mathrm{X}$ $0.25 \mathrm{~mm} \mathrm{X} 0.25 \mu \mathrm{m}$ and a determination method described by Turcu et al, 2020 was used for determination of fatty acids composition. 


\section{Statistics}

General Linear Model (GLM; Minitab version 13; Minitab Inc., State College, PA, USA) followed by Tukey's HSD test $(\mathrm{P}<0.05)$ was applied for statistical comparisons between treatments.

\section{RESULTS}

No significant differences between groups were noticed regarding performance parameters during experimental period (Untea et al., 2019). In table 2 are presented results regarding the proximate composition of thigh meat. Supplementation of broiler diets with 3\% Camelina meal led to significantly $(\mathrm{P}<0.05)$ increased crude fat concentrations in thigh samples compared to control group or with single chromium supplemented groups. Inverselly effect was noticed for chromium supplemented groups: increased concentrations of crude protein (but not statistically sustained) and decreased concencentrations of crude fat compared to Camelina meal supplemented groups. Crude ash was significantly increased for Camelina meal $(\mathrm{P}>0.05)$ groups, compared with others.

Table 2. The Camelina meal and chromium effect on proximate composition of broiler thigh meat

\begin{tabular}{|c|c|c|c|c|c|c|c|c|c|c|}
\hline & \multicolumn{3}{|c|}{ Cam $0 \%$} & \multicolumn{3}{|c|}{ Cam 3\% } & \multirow[t]{2}{*}{ SEM } & \multirow{2}{*}{$\begin{array}{l}\mathbf{P} \\
\mathrm{Cr}\end{array}$} & \multirow{2}{*}{$\begin{array}{l}\mathbf{P} \\
\text { Cam }\end{array}$} & \multirow{2}{*}{$\begin{array}{l}\mathbf{P} \\
\mathrm{Cr} \mathrm{x} \\
\mathrm{Cam}\end{array}$} \\
\hline & $\begin{array}{l}\mathbf{C r} \\
0 \mathrm{ppb}\end{array}$ & $\begin{array}{l}\mathbf{C r} \\
200 \\
\text { ppb }\end{array}$ & $\begin{array}{l}\mathbf{C r} \\
400 \\
\text { ppb }\end{array}$ & $\begin{array}{l}\mathbf{C r} \\
0 \mathrm{ppb}\end{array}$ & $\begin{array}{l}\mathbf{C r} \\
200 \\
\text { ppb }\end{array}$ & $\begin{array}{l}\mathbf{C r} \\
400 \\
\text { ppb }\end{array}$ & & & & \\
\hline DM & $24.46^{\mathrm{ab}}$ & 24.0 & $24.6^{\mathrm{ab}}$ & $25.46^{\mathrm{a}}$ & $25.09^{a b}$ & $25.48^{a}$ & 0.15 & 0.188 & 0.001 & 0.933 \\
\hline $\begin{array}{l}\text { Crude } \\
\text { protein (\%) }\end{array}$ & 18.46 & 18.8 & 18.75 & 18.50 & 18.30 & 18.11 & 0.14 & 0.787 & 0.127 & 0.199 \\
\hline Crude fat $\%$ ) & $4.34^{\mathrm{b}}$ & $4.0^{\mathrm{b}}$ & $4.48^{\mathrm{b}}$ & $5.06^{\mathrm{a}}$ & $4.75^{\mathrm{a}}$ & $5.35^{\mathrm{a}}$ & 0.18 & 0.280 & 0.007 & 0.966 \\
\hline Crud ash (\%) & $0.98^{b}$ & $0.96^{\mathrm{b}}$ & $0.98^{\mathrm{b}}$ & $1.01^{\mathrm{a}}$ & $1.07^{\mathrm{a}}$ & $1.09^{a}$ & 0.026 & 0.679 & 0.03 & 0.675 \\
\hline
\end{tabular}

In our study, the crude protein concentrations range between 18.11 and $18.84 \%$ for thigh samples. Regarding fat content we found 4.02 to $5.35 \%$ in thigh samples. Bogosavljević-Bošković et al. (2010) established based on a literature review that the protein content of thigh muscle ranges between 15.8 to $17.9 \%$ respectively. Some authors consider that dietary fat generally suggested a higher effect on adipose tissue composition than on the meat fat content (Bogosavljević-Bošković et al., 2010). In our study, the groups supplemented with Camelina meal, presented higher fat concentration in thigh muscle, than other groups. Other authors also observed a higher rate of lipids deposition on tissues like breast or thigh when the diets were supplemented with increasing doses of Camelina meal (Aziza et al., 2010) 
proving that the lipid biosynthesis is related to fat dietary origin (Cherian, 2012).

Mineral composition of broiler thigh meat is presented in Table 3. In thigh samples, $\mathrm{Zn}$ and Fe concentrations increased under CrPic influence. The retention of $\mathrm{Cu}$ in thigh samples show no difference between groups.

Table 3. Effect of supplemental CrPic and Camelina meal on mineral composition of broiler thigh meat

\begin{tabular}{|c|c|c|c|c|c|c|c|c|c|c|}
\hline \multicolumn{3}{|c|}{ Cam $0 \%$} & \multicolumn{3}{|c|}{ Cam 3\% } & \multicolumn{3}{|c|}{ SEM } & \multirow[b]{2}{*}{$\begin{array}{c}\mathbf{P} \\
\text { Cam }\end{array}$} & \multirow[b]{2}{*}{$\begin{array}{c}\mathbf{P} \\
\mathrm{Cr} \mathrm{x} \\
\mathrm{Cam}\end{array}$} \\
\hline $\mathrm{mg} / \mathrm{kg}$ & $\begin{array}{c}\mathbf{C r} \\
0 \mathrm{ppb}\end{array}$ & $\begin{array}{c}\mathbf{C r} \\
200 \mathrm{ppb}\end{array}$ & $\begin{array}{c}\mathbf{C r} \\
400 \mathrm{ppb}\end{array}$ & $\begin{array}{c}\mathbf{C r} \\
0 \mathrm{ppb}\end{array}$ & $\begin{array}{c}\mathbf{C r} \\
200 \\
\mathrm{ppb}\end{array}$ & $\begin{array}{c}\text { Cr } \\
400 \\
\text { ppb }\end{array}$ & & $\begin{array}{l}\mathbf{P} \\
\mathrm{Cr}\end{array}$ & & \\
\hline $\mathrm{Zn}$ & $57.59^{b}$ & $62.30^{\mathrm{a}}$ & $61.55^{a}$ & $56.92^{b}$ & $57.70^{b}$ & $57.14^{b}$ & 5.3 & 0.042 & 0.076 & 0.594 \\
\hline $\mathrm{Cu}$ & 2.40 & 2.36 & 2.45 & 2.52 & 2.35 & 2.52 & 0.3 & 0.689 & 0.648 & 0.913 \\
\hline $\mathrm{Fe}$ & 35.45 & 43.66 & 39.11 & 38.41 & 37.01 & 40.1 & 3.8 & 0.027 & 0.387 & 0.001 \\
\hline
\end{tabular}

Chromium effect on mineral utilization and deposition was reported in the scientific literature: in cold stress conditions it was reported an improved utilization of zinc and iron in laying hens (Sahin \& Sahin, 2002); zinc deposition in organs and muscle of laying hens was also reported by Sahin et al., (2002). Some authors considered that chromium and iron are antagonist elements and the presence of chromium may impair the iron absorption (Pechova and Pavlata, 2007). Our results proved a positive effect of trivalent chromium on iron and zinc absorption and deposition. The antioxidant properties of chromium are recognized due to improving insulin metabolism (Sahin et al, 2010) but our results also sustain the hypothesis that a potential mechanism of action can be the stimulating effect on zinc absorption (Untea et al., 2019).

The effects of diets supplementation with chromium and Camelina meal on fatty acids composition of thigh samples (Table 4) revealed a significant decrease of SFA concentrations for the mixture of additives (200 ppb $\mathrm{Cr}$ and 3\% Camelina meal) due to the decreasing effect on palmitic acid and stearic acid. Omega 6 fatty acids concentrations were positive influenced by Chromium presence $(200 \mathrm{ppb})$ both single or in combination. The effect can be attributed to the increased concentrations of linoleic acid in chromium (200 ppb) supplemented groups compared to others. The presence of Camelina meal in the broilers diets, led to increasing omega 3 fatty acids concentrations compared to control group or single chromium supplemented groups.

Our presented findings are in agreement with scientific literature. Other authors noticed the positive influence of Camelina cakes and oils (OrczewskaDudek and Pietras, 2019, Ciurescu et al., 2018), Camelina seeds (Zając et al., 
Table 4. Fatty acids profile of thigh meat samples

\begin{tabular}{|c|c|c|c|c|c|c|c|c|c|c|c|}
\hline \multirow{2}{*}{\multicolumn{2}{|c|}{ Fatty acids }} & \multicolumn{3}{|c|}{ Cam $0 \%$} & \multicolumn{3}{|c|}{ Cam 3\% } & \multirow[t]{2}{*}{ SEM } & \multirow{2}{*}{$\begin{array}{c}\mathbf{P} \\
\mathrm{Cr}\end{array}$} & \multirow{2}{*}{$\begin{array}{c}\mathbf{P} \\
\text { Cam }\end{array}$} & \multirow{2}{*}{$\begin{array}{c}\mathbf{P} \\
\mathrm{Cr} \times \mathrm{Cam}\end{array}$} \\
\hline & & Cr 0 ppb & Cr 200ppb & $\mathrm{Cr} 400 \mathrm{ppb}$ & Cr 0 ppb & Cr $200 \mathrm{ppb}$ & Cr400 ppb & & & & \\
\hline Capric acid & C10:0 & $0.03^{\mathrm{a}}$ & $0.00^{\mathrm{b}}$ & $0.02^{\mathrm{ab}}$ & $0.02^{\mathrm{ab}}$ & $0.03^{\mathrm{a}}$ & $0.02^{\mathrm{ab}}$ & 0.007 & 0.245 & 0.234 & 0.004 \\
\hline Lauric acid & (C12:0) & 0.02 & 0.00 & 0.05 & 0.05 & 0.03 & 0.03 & 0.022 & 0.185 & 0.111 & 0.175 \\
\hline Miristic acid & (C14:0) & $0.57^{\mathrm{a}}$ & $0.55^{\mathrm{ab}}$ & $0.52^{\mathrm{ab}}$ & $0.51^{\mathrm{b}}$ & $0.52^{\mathrm{ab}}$ & $0.55^{\mathrm{ab}}$ & 0.007 & 0.880 & 0.089 & 0.005 \\
\hline Miristoleic acid & C14:1 & 0.19 & 0.16 & 0.18 & 0.17 & 0.18 & 0.21 & 0.006 & 0.231 & 0.407 & 0.155 \\
\hline Pentadecanoic acid & (C15:0) & 0.40 & 0.28 & 0.32 & 0.34 & 0.34 & 0.33 & 0.019 & 0.183 & 0.840 & 0.187 \\
\hline Pentadecenoic acid & (C15:1) & $0.59^{\mathrm{a}}$ & $0.38^{\mathrm{ab}}$ & $0.35^{\mathrm{b}}$ & $0.47 \mathrm{ab}$ & $0.38^{\mathrm{ab}}$ & $0.46^{\mathrm{ab}}$ & 0.029 & 0.017 & 0.930 & 0.079 \\
\hline Palmitic acid & (C16:0) & $21.82^{\mathrm{a}}$ & $20.85^{\mathrm{ab}}$ & $20.44^{\mathrm{ab}}$ & $20.02^{\mathrm{b}}$ & $20.17^{\mathrm{b}}$ & $21.13^{\mathrm{ab}}$ & 0.206 & 0.504 & 0.049 & 0.006 \\
\hline Palmitoleic acid & (C16:1) & 3.14 & 2.79 & 2.83 & 2.88 & 2.90 & 3.03 & 0.165 & 0.615 & 0.910 & 0.332 \\
\hline Heptadecanoic acid & $(\mathrm{C} 17: 0)$ & 0.20 & 0.18 & 0.20 & 0.18 & 0.21 & 0.17 & 0.008 & 0.801 & 0.833 & 0.095 \\
\hline Heptadecenoic acid & (C17:1) & 0.19 & 0.20 & 0.14 & 0.20 & 0.19 & 0.22 & 0.012 & 0.655 & 0.089 & 0.118 \\
\hline Stearic acid & (C18:0) & $7.15^{\mathrm{a}}$ & $7.19 \mathrm{a}$ & $7.34^{\mathrm{a}}$ & $6.95^{\mathrm{b}}$ & $6.48^{\mathrm{b}}$ & $6.95^{\mathrm{b}}$ & 0.130 & 0.386 & 0.026 & 0.528 \\
\hline Oleic acid & (C18:1) & $37.51^{\mathrm{a}}$ & $36.28^{\mathrm{b}}$ & $36.45^{\mathrm{ab}}$ & $37.36^{\mathrm{a}}$ & $36.17 \mathrm{~b}$ & $37.38^{\mathrm{ab}}$ & 0.258 & 0.037 & 0.544 & 0.400 \\
\hline Linoleic acid & (C18:2n-6) & $22.63^{\mathrm{b}}$ & $26.26^{\mathrm{a}}$ & $24.86^{\mathrm{ab}}$ & $24.83^{\mathrm{b}}$ & $26.95^{\mathrm{a}}$ & $24.67 \mathrm{ab}$ & 0.469 & 0.005 & 0.186 & 0.345 \\
\hline Arachidic acid & C20:0 & 0.18 & 0.08 & 0.16 & 0.16 & 0.13 & 0.08 & 0.017 & 0.098 & 0.496 & 0.149 \\
\hline Linolenic acid & $(\mathrm{C} 18: 3 n-3)$ & $0.34 \mathrm{~b}$ & $0.43^{\mathrm{b}}$ & $0.40^{\mathrm{b}}$ & $0,73^{a}$ & $0.83^{\mathrm{a}}$ & $0.68^{\mathrm{a}}$ & 0.024 & 0.060 & 0.001 & 0.260 \\
\hline CLA & C18:2 & $0.18^{\mathrm{ab}}$ & $0.02^{\mathrm{b}}$ & $0.31^{\mathrm{a}}$ & $0.14^{\mathrm{b}}$ & $0.07 \mathrm{~b}$ & $0.02^{\mathrm{b}}$ & 0.021 & 0.004 & 0.004 & 0.001 \\
\hline Octatetraenoic acid & C18:4n3 & 0.41 & 0.35 & 0.39 & 0.34 & 0.30 & 0.37 & 0.021 & 0.241 & 0.133 & 0.878 \\
\hline Eicosadienoic acid & $(\mathrm{C} 20: 2 \mathrm{n}-6)$ & $0.39 \mathrm{~b}$ & $0.31^{\mathrm{b}}$ & $0.36^{\mathrm{b}}$ & $0.57 \mathrm{a}$ & $0.55^{\mathrm{a}}$ & $0.50^{\mathrm{a}}$ & 0.012 & 0.050 & 0.001 & 0.125 \\
\hline Eicosatrienoic acid & $(C 20: 3 n-6)$ & $0.27^{\mathrm{a}}$ & $0.22^{\mathrm{a}}$ & $0.25^{\mathrm{a}}$ & $0.16^{\mathrm{b}}$ & $0.09^{\mathrm{b}}$ & $0.14^{\mathrm{b}}$ & 0.033 & 0.581 & 0.021 & 0.987 \\
\hline Erucic acid & C22: $1 \mathrm{n} 9$ & $0.21^{\mathrm{ab}}$ & $0.19 \mathrm{~b}$ & $0.17 \mathrm{~b}$ & 0.24 ab & $0.20^{\mathrm{b}}$ & $0.44^{\mathrm{a}}$ & 0.031 & 0.135 & 0.027 & 0.043 \\
\hline Eicosatrienoic acid & $(C 20: 3 n-3)$ & $0.14^{\mathrm{b}}$ & $0.25^{\mathrm{a}}$ & $0.25^{\mathrm{a}}$ & $0.24^{\mathrm{a}}$ & $0.27^{\mathrm{a}}$ & $0.20^{\mathrm{ab}}$ & 0.010 & 0.002 & 0.136 & 0.001 \\
\hline Arachidonic acid & $(C 20: 4 n-6)$ & $0.97^{\mathrm{b}}$ & $1.30^{\mathrm{a}}$ & $1.18^{\mathrm{ab}}$ & $0.96^{\mathrm{b}}$ & $0,94^{\mathrm{b}}$ & $0.87^{\mathrm{b}}$ & 0.043 & 0.131 & 0.001 & 0.055 \\
\hline Tricosanoic acid & C23:0 & 0.27 & 0.22 & 0.27 & 0.27 & 0.23 & 0.20 & 0.019 & 0.331 & 0.480 & 0.401 \\
\hline Docosadienoic acid & $\mathrm{C} 22: 2 \mathrm{n} 6$ & 0.26 & 0.23 & 0.25 & 0.25 & 0.23 & 0.23 & 0.033 & 0.775 & 0.840 & 0.964 \\
\hline Eicosapentaenoic acid & C20:5n3 & $0.47 \mathrm{ab}$ & $0.28^{\mathrm{b}}$ & $0.47 \mathrm{ab}$ & $0.49^{a}$ & $0.42^{\mathrm{b}}$ & $0.32^{\mathrm{b}}$ & 0.036 & 0.006 & 0.907 & 0.002 \\
\hline Lignoceric acid & $\mathrm{C} 24: 0$ & $0.52^{\mathrm{a}}$ & $0.50^{\mathrm{a}}$ & $0.52^{\mathrm{a}}$ & $0.51^{\mathrm{a}}$ & $0.48^{\mathrm{ab}}$ & $0.26^{\mathrm{b}}$ & 0.030 & 0.059 & 0.027 & 0.038 \\
\hline Nervonic acid & C24 (1n9) & $0.17^{\mathrm{ab}}$ & $0.11^{\mathrm{ab}}$ & $0.28^{\mathrm{a}}$ & $0.22^{\mathrm{ab}}$ & $0.05^{\mathrm{b}}$ & $0.04^{\mathrm{b}}$ & 0.026 & 0.037 & 0.037 & 0.012 \\
\hline Other fatty acids & & 0.78 & 0.43 & 1.05 & 0.74 & 0.64 & 0.50 & & & & \\
\hline TOTAL & & 100 & 100 & 100 & 100 & 100 & 100 & & & & \\
\hline$\Sigma$ Saturated acids & & $31.17^{a}$ & $29.34^{\mathrm{ab}}$ & $29.83^{\mathrm{ab}}$ & $29.02^{\mathrm{ab}}$ & $28.63^{b}$ & $29.72^{\mathrm{ab}}$ & 0.300 & 0.264 & 0.011 & 0.165 \\
\hline$\Sigma$ Unsaturated acids & & $68.05^{b}$ & $69.74^{\mathrm{ab}}$ & $69.18^{\mathrm{ab}}$ & $70.28^{\mathrm{ab}}$ & $70.75^{a}$ & $69.80^{\mathrm{ab}}$ & 0.304 & 0.127 & 0.005 & 0.303 \\
\hline$\sum n-6$ & & $24.70^{\mathrm{b}}$ & $28.35^{a}$ & $27.22^{\mathrm{ab}}$ & $26.91^{\mathrm{ab}}$ & $28.83^{a}$ & $26.42^{\mathrm{ab}}$ & 0.814 & 0.006 & 0.352 & 0.194 \\
\hline$\Sigma \mathrm{n}-3$ & & $1.35^{c}$ & $1.31^{\mathrm{c}}$ & $1.52^{\mathrm{bc}}$ & $1.80^{\mathrm{a}}$ & $1.82^{\mathrm{a}}$ & $1.56^{\mathrm{b}}$ & 0.028 & 0.773 & 0.001 & 0.001 \\
\hline Ratio n-6/n-3 & & $18.39 \mathrm{~b}$ & $21.73^{\mathrm{a}}$ & $18.11^{\mathrm{b}}$ & $15.00^{c}$ & $15.91^{\mathrm{bc}}$ & $17.02^{\mathrm{bc}}$ & 0.706 & 0.019 & 0.001 & 0.009 \\
\hline
\end{tabular}


2020) or Camelina meal (Untea et al., 2019) on fatty acids profile of animal origin food. Positive influence of chromium on reduction of fat percentage of meat but no significant influence on fatty acids profile, was also noticed by Mir et al., 2017. Han et al., 2021, proved that organic sources of chromium used in broilers diets led to significant increase of omega 3 fatty acids of breast meat. The use of Camelina meal in poultry diets is considered to be a successful approach for fortifying meat in omega 3 fatty acids (Cherian, 2012). In the scientific literature, linseed is known as the main source of unsaturated fatty acids in farm animals diets, but Camelina meal is another oilseed crop with similar efficiency in decreasing the ratio of $n-6 / n-3$ fatty acids in poultry products (Zajak et al., 2020).

\section{CONCLUSION}

The results of the study showed that Camelina meal and chromium picolinate supplements in broilers diets improved the nutritional properties of thigh meat, especially essential minerals content ( $\mathrm{Zn}$ and $\mathrm{Fe}$ ) and fatty acids profile.

\section{ACKNOWLEDGEMENTS}

This research was funded by Romanian Ministry of Research and Digitalization, grant number PN 19090102. 


\section{REFERENCES}

Amer, S. A., Mohamed, W. A., Gharib, H. S., Al-Gabri, N. A., Gouda, A., Elabbasy, M. T., ... \& Omar, A. E., 2021. Changes in the growth, ileal digestibility, intestinal histology, behavior, fatty acid composition of the breast muscles, and blood biochemical parameters of broiler chickens by dietary inclusion of safflower oil and vitamin C. BMC Veterinary Research, 17(1), 1-18.

Anandhi, M., Mathivanan, R., Viswanathan, K., \& Mohan, B., 2006. Dietary inclusion of organic chromium on production and carcass characteristics of broilers. International Journal of Poultry Science, 5(9), 880-884.

Aziza, A. E., Quezada, N., \& Cherian, G., 2010. Feeding Camelinasativa meal to meat-type chickens: Effect on production performance and tissue fatty acid composition. Journal of Applied Poultry Research, 19(2), 157-168.

Cherian, G. (2012). Camelina sativa in poultry diets: opportunities and challenges. Biofuel co-products as livestock feed: opportunities and challenges. Rome: FAO, 303-310.

Ciurescu G., Ropota M. , Toncea I. , and Habeanu M., Camelia (Camelina sativa L. Crantz Variety) Oil and Seeds as n-3 Fatty Acids Rich Products in Broiler Diets and Its Effects on Performance, Meat Fatty Acid Composition, Immune Tissue Weights, and Plasma Metabolic Profile J. Agr. Sci. Tech. 2016 Vol. 18: 315-326

Gao, M., Cieślak, A., Kierończyk, B., Huang, H., Yanza, Y. R., ZaworskaZakrzewska, A., \& Szumacher-Strabel, M., 2020. Effects of Raw and Fermented Rapeseed Cake on Growth Performance, Methane Production, and Breast Meat Fatty Acid Composition in Broiler Chickens. Animals, 10(12), 2250.

Han, M., Chen, Y., Li, J., Dong, Y., Miao, Z., Li, J., \& Zhang, L., 2021. Effects of organic chromium sources on growth performance, lipid metabolism, antioxidant status, breast amino acid and fatty acid profiles in broilers. Journal of the Science of Food and Agriculture.

Kumar, F., Tyagi, P. K., Mir, N. A., Dev, K., Begum, J., Biswas, A., \& Mandal, A. B., 2020. Dietary flaxseed and turmeric is a novel strategy to enrich chicken meat with long chain $\omega-3$ polyunsaturated fatty acids with better oxidative stability and functional properties. Food chemistry, 305, 125458.

Mir, N. A., Tyagi, P. K., Biswas, A. K., Tyagi, P. K., Mandal, A. B., Sheikh, S. A., ... \& Verma, A. K., 2017. Impact of feeding chromium supplemented flaxseed based diet on fatty acid profile, oxidative stability and other 
functional properties of broiler chicken meat. Journal of food science and technology, 54(12), 3899-3907.

Orczewska-Dudek, S., \& Pietras, M., 2019. The effect of dietary Camelina sativa oil or cake in the diets of broiler chickens on growth performance, fatty acid profile, and sensory quality of meat. Animals, 9(10), 734.

Panaite, T. D., Nour, V., Vlaicu, P. A., Ropota, M., Corbu, A. R., \& Saracila, M., 2019. Flaxseed and dried tomato waste used together in laying hens diet. Archives of animal nutrition, 73(3), 222-238.

Panaite, T., Criste, R. D., Ropota, M., Cornescu, G. M., Alexandrescu, D. C., Criste, V., Vasile G., Olteanu M., Untea, A. (2016). Effect of layer diets enriched in Omega-3 fatty acids supplemented with $\mathrm{Cu}$ on the nutritive value of the eggs. Romanian Biotechnological Letters, 21(4), 11754-62.

Pechova, A., \& Pavlata, L., 2007). Chromium as an essential nutrient: a review. Veterinarni Medicina-Praha, 52(1), 1.

Sahin, K., \& Sahin, N., 2002. Effects of chromium picolinate and ascorbic acid dietary supplementation on nitrogen and mineral excretion of laying hens reared in a low ambient temperature $(7 \mathrm{C})$. Acta Veterinaria Brno, 71(2), 183-189.

Sahin, K., Sahin, N., \& Kucuk, O., 2003. Effects of chromium, and ascorbic acid supplementation on growth, carcass traits, serum metabolites, and antioxidant status of broiler chickens reared at a high ambient temperature (32 C). Nutrition Research,23(2), 225-238.

Sahin, N., Akdemir, F., Tuzcu, M., Hayirli, A., Smith, M. O., \& Sahin, K., 2010. Effects of supplemental chromium sources and levels on performance, lipid peroxidation and proinflammatory markers in heat-stressed quails. Animal feed science and technology, 159(3-4), 143-149.

Sahin, N., Onderci, M., \& Sahin, K., 2002. Effects of dietary chromium and zinc on egg production, egg quality, and some blood metabolites of laying hens reared under low ambient temperature. Biological trace element research, 85(1), 47-58.

Toghyani, M., Toghyani, M., Shivazad, M., Gheisari, A., \& Bahadoran, R., 2012. Chromium supplementation can alleviate the negative effects of heat stress on growth performance, carcass traits, and meat lipid oxidation of broiler chicks without any adverse impacts on blood constituents. Biological trace element research, 146(2), 171-180.

Untea, A. E., Panaite, T. D., Dragomir, C., Ropota, M., Olteanu, M., \& Varzaru, I., 2019. Effect of dietary chromium supplementation on meat nutritional quality and antioxidant status from broilers fed with Camelina-mealsupplemented diets. animal, 13(12), 2939-2947.

Zając, M., Kiczorowska, B., Samolińska, W., \& Klebaniuk, R., 2020. Inclusion of camelina, flax, and sunflower seeds in the diets for broiler chickens: apparent digestibility of nutrients, growth performance, health status, and carcass and meat quality traits. Animals, 10(2), 321. 